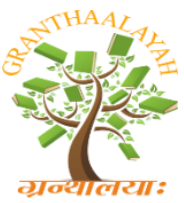

$$
\begin{aligned}
& \text { INTERNATIONAL JOURNAL OF RESEARCH - } \\
& \text { GRANTHAALAYAH } \\
& \text { A knowledge Repository }
\end{aligned}
$$

Social

\title{
AN ANALYSIS OF THE CONTENT WORDS USED IN A SCHOOL TEXTBOOK, TEAM UP ENGLISH 3, USED FOR GRADE 9 STUDENTS
}

\author{
Sukontip Pijarnsarid*1, Prommintra Kongkaew ${ }^{2}$ \\ ${ }^{* 1,2}$ English Department, Graduate School, Ubon Ratchathani Rajabhat University, Thailand
}

DOI: https://doi.org/10.29121/granthaalayah.v5.i3.2017.1761

\begin{abstract}
The purpose of this study were to study the content words used in a school textbook, Team Up in English 3, used for Grade 9 students and to study the frequency of content words used in a school textbook, Team Up in English 3, used for Grade 9 students. The study found that nouns is used with the highest frequency (79), followed by verb (58), adjective (46), and adverb (24). With the nouns analyzed, it was found that the Modifiers $+\mathrm{N}$ used with the highest frequency (92.40\%), the compound nouns were ranked in second $(7.59 \%)$. Considering the verbs used in the text, it was found that transitive verbs were most commonly used $(77.58 \%)$, followed by intransitive verbs (12.06\%), linking verbs (10.34\%). As regards the adjectives used in the text, there were 46 adjectives in total, 30 adjectives were used as attributive $(65.21 \%)$ and 16 adjectives were used as predicative $(34.78 \%)$. As for the adverbs, it was found that adverbs of times were used with the highest frequency $(37.5 \%)$, followed by the adverbs of purpose and degree $(33.33 \%)$, the adverbs of frequency $(12.5 \%)$, the adverbs of place $(8.33 \%)$ and the adverbs of manner $(8.33 \%)$.

Keywords: Content Words; English Textbook; Nouns; Adjective; Verb, Adverb.

Cite This Article: Sukontip Pijarnsarid, and Prommintra Kongkaew (2017). "AN ANALYSIS OF THE CONTENT WORDS USED IN A SCHOOL TEXTBOOK, TEAM UP ENGLISH 3, USED FOR GRADE 9 STUDENTS.” International Journal of Research - Granthaalayah, 5(3), 140-153. https://doi.org/10.29121/granthaalayah.v5.i3.2017.1761.
\end{abstract}

\section{Introduction}

English is an important language to communicate with people other nations. English spread widely all over the world, and is an important key to success if everyone wants to study, to do business, to make new friends, to go aboard, etc. As one of the world's major languages, English is the international language and the common language of humanity to contact between the humans around the world. To interact with people of different languages, different cultures, and different people need to use English as the primary means of interaction. For this reason, all nations, all languages are encased in English as a second language into the national language. It 
is included in the core of the curriculum at all levels from early childhood to adult life. Moreover, nowadays English plays an important role for communication. English has several factors affecting students 'motivation to learn and their success of learning. Textbooks are one important factor affecting the teachers 'teaching and the students' learning. In teaching, textbook is an instrument to determine the direction of the class. It influences the way the teacher sets the lesson plan since it provides the contents and the learning activities to learn in the classroom and it contains the group and individual activities to do outside of the class.

Textbooks are a key component in most language programs. In some situations they serve as the basis for much of the language input learners receive and the language practice that occurs in the classroom. They may provide the basis for the content of the lessons, the balance of skills taught and the kinds of language practice the students take part in. In other situations, the textbook may serve primarily to supplement the teacher's instruction. For learners, the textbook may provide the major source of contact they have with the language apart from input provided by the teacher. In the case of inexperienced teachers textbooks may also serve as a form of teacher training - they provide ideas on how to plan and teach lessons as well as formats that teachers can use. Much of the language teaching that occurs throughout the world today could not take place without the extensive use of commercial textbooks. Learning how to use and adapt textbooks is hence an important part of a teacher's professional knowledge.

English Language Teaching (ELT) textbooks play a very important role in language classrooms. Immanuel (2001) states that textbooks are key components in most language programs. In some situations they serve as the basis for many language inputs that learners receive and language practices that occur in the classroom. They may provide the basis for the content of the lessons, the balance of skills being taught and the kinds of language practice the students take part in. Materials should make students learn. They should also be the resource books for ideas and instructional activities as well as giving teachers rationales for what they do. Learning about the parts of speech is the first step in grammar study just as learning the letters of the alphabet is the first step to being able to read and write. From learning the parts of speech we begin to understand the use or function of words and how words are joined together to make meaningful communication. To understand what a part of speech is, you must understand the idea of putting similar things together into groups or categories.

Each word in English belongs to one of the eight parts of speech: noun, pronoun, verb, adverb, adjective, conjunction, preposition, and interjection. Each word in English is also either a content word or a function word. Content words are nouns, verbs, adjectives and adverbs. A noun tells us about person, place or thing, a verb tells us about the action happening, or the state. Adjectives give us details about objects and people and adverbs tell us how, when or where something is done. Nouns, verbs, adjectives and adverbs give us important information required for understanding.

In other words, content words give us the most important information while function words are used to stitch those words together. Function words help us connect important information. Function words are important for understanding, but they add little in meaning beyond defining the relationship between two words. Function words include: auxiliary verbs, prepositions, articles, conjunctions and pronouns. Auxiliary verbs are used to establish the tense, prepositions 
show relationships in time and space, articles show us something that is specific or one of many, and pronouns refer to other nouns.

Knowing the difference between content and function words is important because content words are stressed in conversation in English. Function words are non-stressed. In other words, function words are not emphasized in speech, while content words are highlighted. Knowing the difference between content and function words can help us in understanding English. The researcher viewed that the usage of content words in text book can be useful to learners of English. This study may pave the way for the instruction of EFL in Thailand, with high standards for creating textbook. With that goal in mind, the researcher undertook the study focusing on the features and the types of the content words mostly used in the text book.

\section{Purposes of the Study}

- To study the content words used in a school textbook, Team Up in English 3, used for Grade 9 students.

- To study the frequency of the content words used in a school textbook, Team Up in English 3, used for Grade 9 students.

\section{Research Questions}

- What types of the content words are used in a school textbook, Team Up in English 3, used for Grade 9 students?

- What is the frequency of each type of the content words used in the school text in the study?

\section{Scope of the Study}

This study aims to analyze the school textbook. It covers the content words used in a school textbook, Team Up in English 3, used for Grade 9 Students. The content words are taken from reading passages of Team Up in English 3.

\section{Significance of the Study}

The study is expected to be helpful to learners in their English using. The learners who know the content words are in a better position to use English correctly and effectively.

\section{Definition of Key Terms}

Definitions of important terms in the present study include:

- School Text book refers to 'Team Up in English 3 student's book' which was published by Aksorn Charoen Tat ACT. Co., Ltd.

- Grade ninth Students refers to the students who study at Mathayomsuksa 3 of Kham Khuankaeochanupratham School. 
- Content Word refers to the grammatical categories which include, nouns, verbs, adjectives, and adverbs.

\section{Previous related studies}

In order to achieve the objectives of the study, the researcher collected previous studies from various secondary sources that are related to this study as case studies.

Ramirez, Setiarini and Ni (2007) studied An error analysis on adjective words order in modifying a noun (a case study at third grade year students. Faculty of letters of Gunadarma University.) The purposes of the study were to identify the understanding of the students in using two or more adjectives to modify a noun and the problem faced by the students. The subject of this study is the third year students, Faculty of Letters of Gunadarma University, year 2004. The numbers of the populations were 85 students. The samples taken are 40 students and the technique employed is random sampling. Based on the analysis, the understandings of the students on adjective word order are good enough, especially when they used two and three adjectives. On the other hand, they have weak understanding in using of four or more adjectives. The problem faced by the students in using two or more adjectives together or modify a noun is they do not know the pattern of adjectives word order, especially, when there two or more adjectives in modifying a noun.

Intratat (2010) studied An Error Analysis in Using English Adjectives by KMUIT Students. The study aimed to investigate the co-occurrences of the students' English adjectives with words from other categories when they are mistaken for verbs. The result obtained from the study shows that Thai students mistook English adjectives for verbs. The students put these English adjective in the co-occurrences which are typical to Thai or applied English rules with Thai verbs. The evidence from this study confirms the hypothesis that Thai students' errors in using English adjectives derive from the interference of their mother tongue.

Khwanhathai (2007) studied A Corpus-Based Analysis of English Adjectives in Travel Articles. The purposes of this study were to investigate the frequency lists, classifications and language pattern of English adjectives. The study was based on coups material comprising 150 travel articles from two newspapers. The Nation and Bangkok Post and three magazines; Kinaree, Sawasdee and E-magazines from January 2000-December 2004. The results of the study showed that 2,321 adjectives occurred from 899 qualitative adjectives and 1,422 classifying adjectives. The frequency of the adjectives appearing from 1-327 times was totally 17,238 words or 10 percent of corpus. The top five most frequent adjectives of the qualitative group were small, few, many, new and old and of the classifying group were Thai, local, other, national and another.

Sihombing (2008) conducted a study on The Morphological Process of Adjectives. The aims of this study were to find out affixes that can change the adjective class into other word classes, to focus on the affixes as the markers in adjective class, and to know what is the most productive and the most unproductive affix in adjective class. The method that is used by the author is qualitative descriptive method. The instrument of this study collected 100 samples of adjective base words from article in magazine by scanning. The author concluded that the markets of the adjective class are in-,im-,il-,dis-,un-,-er,-est,-ant,-ive,-ed,-ing,-ful,-less and -al. When the 
adjectives are attached to some affixes, such as en-,-en,-ify,-ize,-ity,-ist,-th,and -ly, they transpose the word class of adjectives. From the instrument of the author the most productive is affix-ly, it can be combined with 84 samples of adjectives from total numbers 100 adjectives that the author has collected. While other are -er,-est,-ness,-ty,-en,un-,-ize,-ish,-th,-im,-in,-fy,en,ir-,il-,and dis-,they are less productive. On the other hand, the least productive or the most unproductive affixed are ir-,il-,and dis-.Each of them only can be combined with on adjective.

Amporn (2005) conducted a study on Developing A Grammar-In-Context Model for EFL Adult Learners, there are three groups: two experimental groups and one control group. The82 subjects in the experimental group 1 received the Grammar-in-Context tasks with task directions to search for a rule .The 76 subjects in experimental group 2 received the Grammar in-Context task without task directions to search for a rule. The results revealed that there were no significant differences among the three group at linguistic level. There were significant differences among the three group at the discourse level at the significance level of .05.The post-test scores of the Grammar-in-Context group with task directions to search for a rule were slightly greater than those of the Grammar-in-Context group without task directions to search for a rule but significantly greater than those of the traditional group.

Liping (2009) studied The Most Frequent Vocabulary in English Textbooks for Grades 1-3.The aim of this study was to find a list of the first 500 words most frequently appearing in textbooks these young learners need to learn and to compare the list with three other most frequently quoted lists. A corpus of 146,192 running words first complied from 501 lessons of the series of textbooks. From this initial corpus, a total of 3,818 words types in frequency rank were identified from running the Range GLS and manually lemmatized to extract all base forms. With the proper nouns eliminate, the same process was undertaken for nouns, lemmatizing plural and possessive forms into uninflected head word entries. As a result, 500 words occurring at the higher frequency were selected. Five experienced primary level EFL teachers, two Thais, two ESL speakers and one native speaker of English, were asked to validate the list. They decided whether the controversial words from the main list in question should be included in or excluded from the finalized word list and replaced with substitute words from the supplementary 115-word list. Finally, the Most Frequent 500-Word List for Grades 1-3 was yielded. To further investigate whether the words in the Most Frequent 500-word List for Grades 1-3 appeared in three popular words lists, the General Service List created by Michael West, the Oxford Word List, and the Dolch Basic Word List, comparisons were made to see if there was any overlap among the vocabulary. The results showed the percentage of overlap increased with a decrease in size of word lists and that there was a very high percentage of overlap between the Dolch Basic Word List and the present study's Most Frequent 500-word list.

\section{Materials and Methods}

The material used in the study is Team Up in English 3 which is used for Grade 9 or Mathayomsueka 3 in Thailand. This school text is published by Aksorn Charoen Tat ACT. Co., Ltd. in 2012.The textbook has 12 chapters in total. Some chapters have two or three reading passages. 


\section{Data Collection}

Only four short reading passages are selected for an analytic purpose. The selected reading passages are given below:

- Starbucks or Little Bettys?

- Record Breaker

- A Day in the Life of a Paramedic

- What's it made of?

\section{Data Analysis}

- Data on the content words in the text are collected from a school textbook, Team Up in English 3, used for Grade 9 students.

- Four reading passages from Team Up in English 3 are selected.

- All selected reading passages to find out the content words as used in the text is read.

- All content words found in the text is identified and collected.

- All content words are classified into major categories and then subdivided into minor categories. First, they are divided into four major content words: nouns, verbs, adjectives, and adverbs. Next, each part is further divided into small categories. Nouns are divided into the following: noun modifiers, and compound. Verbs are divided into transitive, intransitive, and linking verbs. Adjectives are categorized into attributive and predicative. Adverbs are analyzed in terms of the adverbs of time, place, manner, frequency, purpose and degree.

- All content words are to be calculated to examine the frequency of their use in the text.

\section{Results and Discussions}

\subsection{Analysis of Content Words Used in the First Reading Passage}

Table 3.1.1: Nouns used in Starbucks or Little Bettys?

\begin{tabular}{|c|c|c|c|c|}
\hline & \begin{tabular}{|r} 
Types $\begin{array}{r}\text { of } \\
\text { nouns }\end{array}$ \\
\end{tabular} & Examples of nouns found & Total & $(\%)$ \\
\hline 1 & Modifiers $+\mathrm{N}$ & $\begin{array}{l}\text { The coffee bar trend, a traditional English } \\
\text { tearoom, afternoon tea, strawberry jam, a few } \\
\text { families, some old ladies, young people, the } \\
\text { perfect place, a good cup, an American coffee } \\
\text { shop, a really long list, a half fat decaf,an Ice } \\
\text { Vanilla, my way }\end{array}$ & 14 & 82.35 \\
\hline \multirow[t]{2}{*}{2} & Compound & teenagers, take-away service, breakfast & 3 & 17.64 \\
\hline & & & 17 & 99.99 \\
\hline
\end{tabular}

Table 3.1.2: Verbs used in Starbucks or Little Bettys?

\begin{tabular}{|c|c|c|c|c|}
\hline Types & \begin{tabular}{|r} 
of \\
verbs \\
\end{tabular} & Examples of verb found & Total & $(\%)$ \\
\hline 1 & ransitive & drink, serves , spoke , told , sold , have , decided & 9 & 69.23 \\
\hline
\end{tabular}




\begin{tabular}{lrrrr}
\hline \multicolumn{4}{c}{ buy, like } \\
\hline 2 & Intransitive & went , come, & 2 & 15.38 \\
\hline 3 & Linking & A traditional English tea room is small and cozy, & 2 & 15.38 \\
& & I was interested. & \\
\hline & & 13 & 99.99 \\
\hline
\end{tabular}

Table 3.1.3: Adjectives used in Starbucks or Little Bettys?

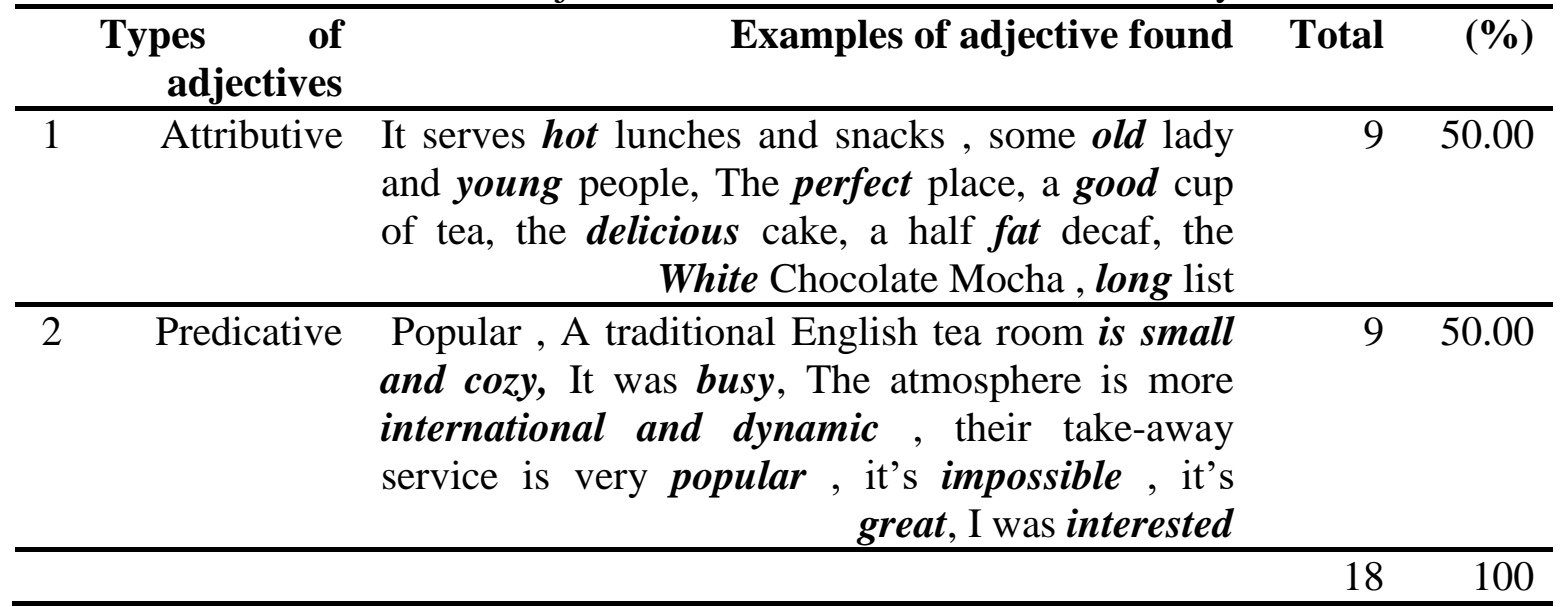

Table 3.1.4: Adverbs used in Starbucks or Little Bettys?

\begin{tabular}{|c|c|c|c|c|}
\hline & $\begin{array}{r}\text { Types of } \\
\text { adverbs }\end{array}$ & Examples of adverb found & Total & $(\%)$ \\
\hline 1 & Time & I never have breakfast at home now & 1 & 16.66 \\
\hline 2 & Place & We always come here & 1 & 16.66 \\
\hline 3 & Manner & - & 0 & 0 \\
\hline 4 & Frequency & $\begin{array}{r}\text { We always come here, I never have breakfast at } \\
\text { home now }\end{array}$ & 2 & 33.33 \\
\hline \multirow[t]{2}{*}{5} & $\begin{array}{r}\text { Purpose and } \\
\text { degree } \\
\end{array}$ & $\begin{array}{r}\text { We always come here, especially after school, I } \\
\text { just buy a Latte on my way to work }\end{array}$ & 2 & 33.33 \\
\hline & & & 6 & 99.98 \\
\hline
\end{tabular}

3.2.Analysis of the Content Words Used in the Second Reading Passage

Table 3.2.1: Nouns used in Record Breaker.

\begin{tabular}{|c|c|c|c|c|}
\hline & $\begin{array}{lr}\text { Types } & \begin{array}{r}\text { of } \\
\text { nouns }\end{array}\end{array}$ & Examples of noun found & Total & $(\%)$ \\
\hline $\begin{array}{l}1 \\
\text {. }\end{array}$ & Modifiers $+\mathrm{N}$ & $\begin{array}{l}\text { 100metres, } 8 \text { miles, } 11-13 \text { category, numerous } \\
\text { medals, many records, } 17100 \text { meter record, } \\
16.6 \text { seconds, the same record, the Under } 20 \\
\text { category, } 16.3 \text { second, the Young Disabled } \\
\text { Sportsperson of the Year 'award, his most } \\
\text { recent award, a spectacular silver medal, the }\end{array}$ & 21 & 95.45 \\
\hline
\end{tabular}


Beijing Paralimpic Games in 2008 , the most important thing, all problems, martial arts, UFC and K-1 Boxing, his box , bacon and tomato sauce

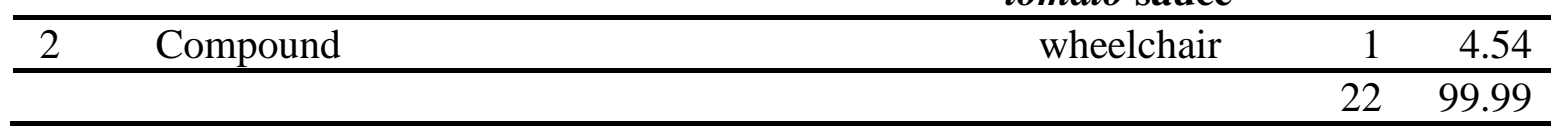

Table 3.2.2: Verbs used in Record Breaker

\begin{tabular}{rrrrr}
\hline & Types $\begin{array}{r}\text { of } \\
\text { verbs }\end{array}$ & Examples of verb found & Total & $(\boldsymbol{\%})$ \\
\hline 1 & Transitive & started , broke, won , do , want, says, enjoys , \\
& races, overcome & 9 & 90.00 \\
\hline 2 & Intransitive & - & 0 & 0 \\
\hline 3 & Linking & he was only 12 & 1 & 10.00 \\
\hline & & & 10 & 100 \\
\hline
\end{tabular}

Table 3.2.3: Adjectives used in Record Breaker

\begin{tabular}{ccccc}
\hline & $\begin{array}{c}\text { Types of } \\
\text { adjectives }\end{array}$ & Examples of adjective found & Total & (\%) \\
\hline 1 & Attributive & $\begin{array}{l}\text { Mickey won numerous medals, His most } \text { recent } \\
\text { award was a spectacular silver medal, the Beijing } \\
.\end{array}$ & $\begin{array}{l}\text { Paralympic games in 2008, the most } \text { important } \\
\text { thing, including martial arts like UFC and K-1 } \\
\text { Boxing, }\end{array}$ & 70.00 \\
& & 30.00 \\
\hline 2 & Predicative & He was born on $8^{\text {th }}$ June 1990,it's important, the \\
most important thing is to be passionate, & 3 & 300 \\
\hline & & & 10 & 100.0 \\
\hline
\end{tabular}

Table 3.2.4: Adverbs used in Record Breaker

\begin{tabular}{rrrrr}
\hline & $\begin{array}{r}\text { Types } \begin{array}{r}\text { of } \\
\text { adverbs }\end{array} \\
\text { Time }\end{array}$ & Then, in 2007, he broke the same record.., When \\
he isn't training... & 2 & 66.66 \\
\hline 1 & Place & - & 0 & 0 \\
\hline 2 & Manner & - & 0 & 0 \\
\hline 3 & Whamples of adverb found & Total & (\%) \\
\hline 4 & Frequency & - & 0 & 0 \\
\hline 5 & $\begin{array}{rlrr}\text { Purpose and } \\
\text { degree }\end{array}$ & When 12 only & 1 & 33.33 \\
\hline & & & 3 & 99.99 \\
\hline
\end{tabular}




\subsection{Analysis of Content Words Used in the Third Reading Passage}

Table 3.3.1: Nouns used in A Day in the Life of a Paramedic

\begin{tabular}{|c|c|c|c|c|}
\hline & $\begin{array}{lr}\text { Types } & \text { of } \\
\text { nouns }\end{array}$ & Examples of noun found & Total & $(\%)$ \\
\hline 1 & Modifiers $+\mathrm{N}$ & $\begin{array}{l}\text { The } T V \text { show, the } A \& E \text { department } \\
\text { incomprehensible things, those people, a road } \\
\text { accident, a sudden illness, the first medical } \\
\text { person, immediate care, the patient's health, } \\
\text { vital information, a very difficult job ,some } \\
\text { example, an air ambulance, my job, a good } \\
\text { feeling,emergency situation, }\end{array}$ & 16 & 100 \\
\hline \multirow[t]{2}{*}{2} & Compound & - & 0 & 0 \\
\hline & & & 16 & 100 \\
\hline
\end{tabular}

Table 3.3.2: Verbs used in A Day in the Life of a Paramedic

\begin{tabular}{|c|c|c|c|c|}
\hline & $\begin{array}{rr}\text { pes } \begin{array}{r}\text { of } \\
\text { verbs }\end{array} \\
\end{array}$ & Examples of verb found & Total & $(\%)$ \\
\hline 1 & Transitive & $\begin{array}{r}\text { seen, tell , pass made ,know, start, assess, } \\
\text { continue, enjoy, shout go, }\end{array}$ & 11 & 55.00 \\
\hline 2 & Intransitive & run, arrive, remain, get out, shout & 5 & 25.00 \\
\hline 3 & Linking & $\begin{array}{r}\text { I am one of those people, if a patient is seriously } \\
\text { ill, }\end{array}$ & 2 & 10.00 \\
\hline & & & 18 & 100.0 \\
\hline
\end{tabular}

Table 3.3.3: Adjectives used in A Day in the Life of a Paramedic

\begin{tabular}{ccccc}
\hline & $\begin{array}{c}\text { Types of } \\
\text { adjectives }\end{array}$ & Examples of adjective found & Total & $(\%)$ \\
\hline 1 & Attributive & $\begin{array}{c}\text { incomprehensible things, if there's a road accident } \\
\text { or a sudden illness, I am the first medical person, } \\
\text { vital information, difficult job, it's a good feeling, }\end{array}$ & 6 & 85.71 \\
& & You have to remain very calm & 1 & 14.28 \\
\hline 2 & Predicative & & 7 & 99.99 \\
\hline
\end{tabular}

Table 3.3.4: Adverbs used in A Day in the Life of a Paramedic

\begin{tabular}{|c|c|c|c|c|}
\hline & $\begin{array}{r}\text { Types of } \\
\text { adverbs }\end{array}$ & Examples of adverb found & Total & $(\%)$ \\
\hline 1 & Time & $\begin{array}{l}\text { If you start to panic, then everyone will start .., } \\
\text { I'm studying for some exams at the moment, } \\
\text { When we arrive at the hospital.. }\end{array}$ & 3 & 42.85 \\
\hline 2 & Place & - & 0 & $\overline{0}$ \\
\hline 3 & Manner & If a patient is seriously ill.. & 1 & 14.28 \\
\hline 4 & Frequency & Have you ever seen the people on the TV.. & 1 & 14.28 \\
\hline 5 & Purpose and & it can be a very difficult job, I really enjoy my job & 2 & 28.57 \\
\hline
\end{tabular}


degree

$7 \quad 99.98$

\subsection{Analysis of Content Words Used in the Fourth Reading Passage}

Table 3.4.1: Nouns used in What's it made of?

\begin{tabular}{|c|c|c|c|c|}
\hline & \begin{tabular}{|rr} 
Types $\begin{array}{r}\text { of } \\
\text { nouns }\end{array}$ \\
\end{tabular} & Examples of noun found & Total & $(\%)$ \\
\hline 1 & Modifiers $+\mathrm{N}$ & $\begin{array}{l}15 \text { million plastic bottles, 275,000tonnes, every } \\
\text { year, another use, plastic bottles, the first fleece, } \\
\text { an American company, recycled plastic, all } \\
\text { kinds of clothes, baby clothes, the used plastic } \\
\text { bottles, recycling banks, different types, The } \\
\text { PET plastic, a reprocessing plant, small pieces, } \\
\text { the synthetic fibers, these fibers, the fleece } \\
\text { fabric, less oil, fewer toxic emissions, the fleece } \\
\text { sweatshirt }\end{array}$ & 22 & 91.66 \\
\hline \multirow[t]{2}{*}{2} & Compound & Sweatshirts, a sweatshirt & 2 & 8.33 \\
\hline & & & 24 & 99.99 \\
\hline
\end{tabular}

Table 3.4.2: Verbs used in What's it made of?

\begin{tabular}{|c|c|c|c|c|}
\hline & pes $\begin{array}{r}\text { of } \\
\text { verbs }\end{array}$ & Examples of verb found & Total & $(\%)$ \\
\hline $\begin{array}{l}1 \\
.\end{array}$ & Transitive & $\begin{array}{l}\text { used, know, thrown away ,called, creates, mean, } \\
\text { put, cut, sent, made, separated, melted, released, } \\
\text { thrown, collected, woven }\end{array}$ & 16 & 94.11 \\
\hline 2 & Intransitive & - & 0 & 0 \\
\hline 3 & Linking & you are wearing & 1 & 5.88 \\
\hline & & & 17 & 99.99 \\
\hline
\end{tabular}

Table 3.4.3: Adjectives used in What's it made of?

\begin{tabular}{|c|c|c|c|c|}
\hline & $\begin{array}{rr}\text { Types of } \\
\text { adjectives } \\
\end{array}$ & Examples of adjective found & Total & $(\%)$ \\
\hline 1 & Attributive & $\begin{array}{l}\text { a reprocessing plant, the first fleece, the recycling } \\
\text { bank, different type of plastic, small piece, a } \\
\text { special machine, the synthetic fibers, toxic } \\
\text { emissions }\end{array}$ & 8 & 72.72 \\
\hline \multirow[t]{2}{*}{2} & Predicative & $\begin{array}{r}\text { It be better, you are wearing is not only cool, but } \\
\text { environmentally friendly too! }\end{array}$ & 3 & 27.27 \\
\hline & & & 11 & 99.99 \\
\hline
\end{tabular}


Table 3.4.4: Adverbs used in What's it made of?

\begin{tabular}{rrrrrr}
\hline & $\begin{array}{r}\text { Types } \\
\text { adverbs }\end{array}$ & Examples of adverb found & Total & $(\%)$ \\
\hline 1 & Time & $\begin{array}{r}\text { Now, fleece is used to make all kinds.., yesterday, } \\
\text { When was this first done?, Then they are melted.. }\end{array}$ & 3 & 37.50 \\
\hline 2 & Place & Here, the bottles are cut.. & 1 & 12.5 \\
\hline 3 & Manner & But environmentally friendly too! & 1 & 12.5 \\
\hline 4 & Frequency & - & 0 & 0 \\
\hline 5 & $\begin{array}{r}\text { Purpose and } \\
\text { degree }\end{array}$ & $\begin{array}{l}\text { Well, maybe you're wearing plastic bottles!, So, } \\
\text { the fleece } \\
\end{array}$ & $\begin{array}{l}\text { sweatshirt you're wearing is not only } \\
\text { cool, But environmentally friendly too! }\end{array}$ & 37.50 \\
\hline & & & 8 & 100.0 \\
\hline
\end{tabular}

Table 3.5: The details of all content words used as found in the four short reading passage.

\begin{tabular}{llll}
\hline The content words & Types & total & $\mathbf{( \% )}$ \\
\hline Noun used & Modifiers $+\mathrm{N}$ & 73 & 92.40 \\
\cline { 2 - 4 } & Compound & 6 & 7.59 \\
\cline { 2 - 4 } & Total & $\mathbf{7 9}$ & $\mathbf{9 9 . 9 9}$ \\
\hline Verb used & Transitive & 45 & 77.58 \\
\cline { 2 - 4 } & Intransitive & 7 & 12.06 \\
\cline { 2 - 4 } & Linking & 6 & 10.34 \\
\cline { 2 - 4 } & Total & $\mathbf{5 8}$ & $\mathbf{9 9 . 9 8}$ \\
\hline Adjective used & Attributive & 30 & 65.21 \\
\cline { 2 - 4 } & Predicative & 16 & 34.78 \\
\cline { 2 - 4 } & Total & $\mathbf{4 6}$ & $\mathbf{9 9 . 9 9}$ \\
\hline Adverbs used & Time & 9 & 37.5 \\
\cline { 2 - 4 } & Place & 2 & 8.33 \\
\cline { 2 - 4 } & Manner & 2 & 8.33 \\
\cline { 2 - 4 } & Frequency & 3 & 12.5 \\
\cline { 2 - 4 } & Purpose and degree & 8 & 33.33 \\
\cline { 2 - 4 } & Total & $\mathbf{2 4}$ & $\mathbf{9 9 . 9 9}$ \\
\hline
\end{tabular}

\section{Discussion}

Content words also known as open categories are very essential to learning language as they play a key role to help learners understand the text they are reading, denotations and connotations. The messages can be intelligible to receivers even they are communicate with only content words. On the contrary, there is a category called the function words that are opposite to the content words. The function words are also called 'the closed class'. They include prepositions, conjunctions, pronouns and interjections. Their examples are 'at, on, but, and, he. One will find intelligible the message being conveyed in these words. These categories serve a grammatical 
function. Unlike the content words, these words can be expanded. For example, it is not possible to add suffixes or prefixes to prepositions or conjunctions: and-ness, his -ality. In the present study, nouns are found to have been used with the highest frequency. This is because in learning any language humans usually start with nouns in order to refer to things, persons, objects around them. This is the most common and natural method of learning a language. Out of the types of nouns under study, the modifiers+ nouns are in the highest use, followed by the compound nouns.

Therefore, in teaching and learning English, attention should be focused on the nouns first. In that attention should be focused on the principles of simplicity, frequency, usefulness and expandability of the nouns. As a result, the content words used in the school text in the study are mostly short, and simple. In contrast, longer words or compound words are less frequently used. As the longer words many pose a problem to learners at this level, they are avoided or are used as less as possible. Concerning the verbs used in the text, it was found that transitive verbs were used with the highest frequency. Possibly, this verb demonstrates the message more clearly with a verb object. Second in use was the intransitive verb. The reason may be that intransitive verbs do not need an object to complete the message sent. That may be problematic to beginner learners. As a result, they are not used as frequency as the transitive verbs. The liking verb came third in use because this type of verb can be difficult to use as some linking verbs can function as a transitive and linking verb for example, the word "grow" can be a transitive verb as in the sentence "They grow a crop". It can able to be a linking verb, for example, "They grow old".

Therefore, this type of the verb can be a problem for learners or students. The users or writers have to use the linking verbs as less as possible to avoid causing confusion to learners.

As regards the adjectives used in the text in the study, they are analyzed in terms of their grammatical functions: attributive and predicative. It is found that the attributive adjectives were used with the higher frequency $(65.21 \%)$ while the predicative adjectives are used with a lower frequency $(34.78 \%)$. The possible explanation is that a noun is often modified by adjectives. This structure is highly frequently found in reading passages. On the contrary, the predicative adjectives usually come after a linking verb which is not frequently used as compared to the premodifying adjectives. Furthermore, the adjectives are used to describe nouns more frequency. Thus, they are more commonly used as attributive and often found the text in the study. Considering the adverbs used in the text, there are 24 adverbs in total. The adverbs of time are used with the highest frequency (37.5\%). The possible reason is that this type of adverbs is always related to time and incidents in our life. From dusk to dawn, humans are one way or another related to time. The adverbs is ranked in second use is the adverbs of purpose and degree (33.33\%). One can say that the content words are necessary to learning languages and communicating. Out of the four categories, nouns and verbs are used with higher degree. Therefore, it is reasonable to focus more attention on these two classes to maximize learning ability on learners' part. If the learners have understood the content words, their learning of a foreign language is more efficient. Their skills in other aspects will be greatly increased. In addition, they will find it less problematic when it comes to deal with higher level like sentences, paragraphs and discourses. Thus, it is essential for learners to understand the importance of the content words and use them correctly. 


\section{Conclusions \& Recommendations}

The study aimed to analyze the content words used in the school text, Team Up in English 3, used for Grade 9 students and to study the frequency of the content words used in a school textbook, Team Up in English 3, used for Grade 9 students. The study found that out of four content words: nouns, verbs, adjectives, and adverbs, the type which is used with the highest frequency is a noun (79), followed by a verb(58), an adjective (46), and an adverb (24).

With the nouns analyzed, it was found that the Modifiers $+\mathrm{N}$ was used with the highest frequency $(92.40 \%)$, the compound nouns were ranked in second(7.59\%). Considering the verbs used in the text, it was found that transitive verbs were most commonly used $(77.58 \%)$, followed by intransitive verbs (12.06\%), linking verbs $(10.34 \%)$.

As regards the adjectives used in the text, there were 46 adjectives in total. 30 adjectives were used as attributive $(65.21 \%)$ and 16 adjectives were used as predicative $(34.78 \%)$. As for the adverbs, it was found that the adverbs of times were used with the highest frequency ( $37.5 \%)$, followed by the adverbs of purpose and degree ( $33.33 \%)$, the adverbs of frequency $(12.5 \%)$, the adverbs of place $(8.33 \%)$ and the adverbs of manner $(8.33 \%)$.

\section{General Recommendations}

In learning and teaching a foreign language, it is essential to prioritize the content words. In teaching words, teachers have to consider the rules of simplicity, frequency, usefulness and expandability. In addition the teachers have to give priority to nouns, verbs, adjectives and adverbs respectively.

\section{Recommendations for Further Study}

- A further study should be conducted at a more advanced level, for example the higher secondary level.

- A further study should be conducted in other types of text, for example song, poetry, short story, newspaper editorials.

- A further study should examine what content words learners can learn easily and retain longer

\section{Acknowledgements}

I would like to express my gratitude to all those who gave me the opportunity to complete this study. First of all, I would like to express my sincere gratitude to my advisor, Dr.Prommintra Kongkeaw, for giving me an insightful advice and comment throughout my study and his close look at the final version of the study for English style and grammar, correcting and offering suggestions for improvement. I furthermore thank all instructors that have taught me and pushed me to reach this point. Special thanks must be passed to my companions in MA 11 class who always not only shared pleasure and enjoyment but also gave the impression of friendship and care along the ways, especially, Ms.Tanitapuk who supported me with her concern whenever I was disappointed. I also thank my friends, Ms.Arunrat Angkaew and Mr.Tanawat 
Wongchompoo who always provide encouragement whenever I am disheartened. Two more special persons I really appreciate their dedication are my beloved mother and father who have given me the best feeling with their "unconditional love" that cannot be described in words but can keep me strong enough to struggle against any unexpected obstacles in life. Thank you.

\section{References}

[1] Amporn, S. (2006). Developing A Grammar-In-Context Model for EFL Adult Learners. Doctor thesis of Philosophy in English, Suranaree University

[2] Immanuel, A. (2001). The Role of Material in a Language Classroom. Anti-Essays. Retrieved February 10, 2013 from http://www.antiessays.com/free-essays/65043.html.

[3] Inthatat, C. (2010). Thai Errors in Using English Adjectives. Thailand TESOL

[4] Khwanhathai, P. (2007). A corpus-based analysis of English adjectives in travel articles. Master thesis of Arts in English, Khon Kean University.

[5] Liping, H. (2009). The Most Frequent Vocabulary in English Textbooks for Grades 1-3.Master thesis of Arts in English, Suranaree University of Technology.

[6] Ramirez, M., Setiarini, K., \& Ni, L., (2007). An Error Analysis on Adjective Word Order in Modifying a Noun (A Case Study at Third Grade Year Students, Faculty of Letters of Gundarma University). Retrieved March 14, 2013 from http://www.gunadarma.ac.id.

[7] Sihombing, K. (2008). The Morphological Process of English Adjectives. A Thesis of an Undergraduate Degree, Faculty of Letter: English Department, Gunadarma University, Depok.

*Corresponding author.

E-mail address: nootprapa@gmail.com 